\title{
Linfoma não-Hodgkin extralinfonodal gástrico: estudo retrospectivo do serviço de Hematologia do Hospital das Clínicas da Faculdade de Medicina da Universidade de São Paulo
}

\author{
Gastric extranodal non-Hodgkin's lymphoma: retrospective study at the Hematology Department of \\ the Clinic Hospital of the University of São Paulo
}

Renata O. Costa

Orientador: Dalton A. F. Chamone

\section{Resumo}

Aproximadamente $40 \%$ dos casos de Linfoma não-Hodgkin (LNH) se originam fora dos linfonodos, sendo então denominados linfomas extralinfonodais. No trato gastrointestinal (TGI), o estômago é o local mais freqüentemente envolvido, representado pelo linfoma MALT e pelo linfoma difuso de grandes células B (LDGCB). No Brasil, apesar da sua freqüência e importância, existem poucos dados epidemiológicos em relação aos linfomas, especialmente no que se refere aos linfomas de origem extralinfonodal. Para avaliar as características dos linfomas primários gástricos em uma população brasileira, 60 casos foram avaliados retrospectivamente. Trinta e oito $(63,3 \%)$ foram classificados como LDGCB e $22(36,6 \%)$ como MALT. Entre os dois grupos, não houve diferenças significativas em termos de sexo, idade, sintomas dispépticos, sintomas "B", presença de massa Bulky, infiltração de medula óssea, estádio, infecção por H. pylori, achados laboratoriais e endoscópicos. Foram adotados diferentes protocolos de tratamento. A taxa de remissão completa foi de $73,1 \%$ no LDGCB e de $95 \%$ no linfoma MALT. A taxa de sobrevida livre de doença em sete anos foi de $84,8 \%$ no LDGCB e de $94,1 \%$ no linfoma MALT. A taxa de sobrevida global em sete anos foi de $65,7 \%$ no LDGCB e de $92,9 \%$ em cinco anos no linfoma MALT. Como não conseguimos demonstrar diferenças entre os dois tipos histológicos, concluímos que o diagnóstico histológico correto é essencial para a terapêutica mais adequada.

Palavras-chave: Linfoma não-Hodgkin; linfonodos; estudos retrospectivos; hospitais universitários.

\section{Abstract}

Approximately $40 \%$ of the non-Hodgkin's Lymphomas occur outside lymph node tissue and thus are denominated extranodal lymphoma. In the gastrointestinal tract, the stomach is the commonest location involved with the presentation of MALT and diffuse large B-cell lymphomas (DLBCL). In Brazil, despite their importance and frequency there are very few epidemiological data concerning lymphomas, especially those of extranodal origin. In order to study the features of primary gastric lymphomas in a Brazilian population, 60 patients were retrospectively evaluated. Thirty-eight cases (63.3\%) were classified as DLBCL and $22(36.6 \%)$ as MALT lymphoma. There were no significant differences between the 2 groups in terms of gender, age, gastric symptoms, "B" symptoms, bulky disease, bone marrow infiltration, stage, $\mathrm{H}$. pylori infection and laboratory and endoscopic findings. Different treatment methods were adopted. The complete remission rate was $73.1 \%$ for DLBCL and $95 \%$ for MALT lymphoma. The disease free survival at 7 years was 84.8 for DLBCL and $94.1 \%$ for MALT lymphoma. The 7 year overall survival rate for DLBCL was $65.7 \%$ and 5 year overall survival for MALT was $92.9 \%$. As we could not demonstrate differences between the two histological types, we conclude that a correct histological diagnosis is essential for choosing the best therapeutic approach.

Key words: Non-Hodgkin's lymphoma; lymph nodes; retrospective study; university hospitals.

\begin{abstract}
Avaliação: A RBHH publica os resumos e abstracts de teses da área apresentados em entidades que tenham programas de pós-graduação reconhecidos pelo $\mathrm{MEC/Capes} \mathrm{e} \mathrm{considera} \mathrm{a} \mathrm{obtenção} \mathrm{do} \mathrm{título}$ suficiente para sua publicação na forma como se propõe a seção.
\end{abstract}

Recebido: 01/07/2008; Aceito: 03/07/2008 